\title{
I Jornades sobre energia i tecnologia per a professors al Museu del Gas de la Fundació Gas Natural Fenosa
}

\author{
Museu del Gas (museugasfgnf@gasnatural.com) \\ Fundació Gas Natural Fenosa
}

Mestres i professors, van trobar, al Museu del Gas, eines i recursos per poder aplicar nous mètodes i propostes didàctiques per l'ensenyament sobre energia i tecnologia a les aules.

Els dies 4 i 5 d'octubre de 2013 el Museu del Gas de la Fundació Gas Natural Fenosa va organitzar a la seva seu de Sabadell les I Jornades sobre energia i tecnologia per a professors, destinat a mestres de Cicle Superior d'Educació Primària i professors d'Educació Secundària.

Parlar de ciència i tecnologia en un món tan complex i que evoluciona tan ràpid com el nostre resulta una tasca difícil pels mestres i professors que afronten un curs escolar amb els seus alumnes. Des de la Fundació Gas Natural Fenosa i, en concret, amb la voluntat didàctica i divulgativa del Museu del Gas, es va considerar que calia donar el suport necessari a aquells professionals de la docència que busquen recursos i coneixement per a poder impartir la millor de les formacions als seus alumnes.

Les jornades, reconegudes pel Departament d'Ensenyament de la Generalitat de Catalunya, van combinar la formació teòrica amb l'experimentació pràctica oferint als participants un punt de trobada dinàmica i enriquidora.

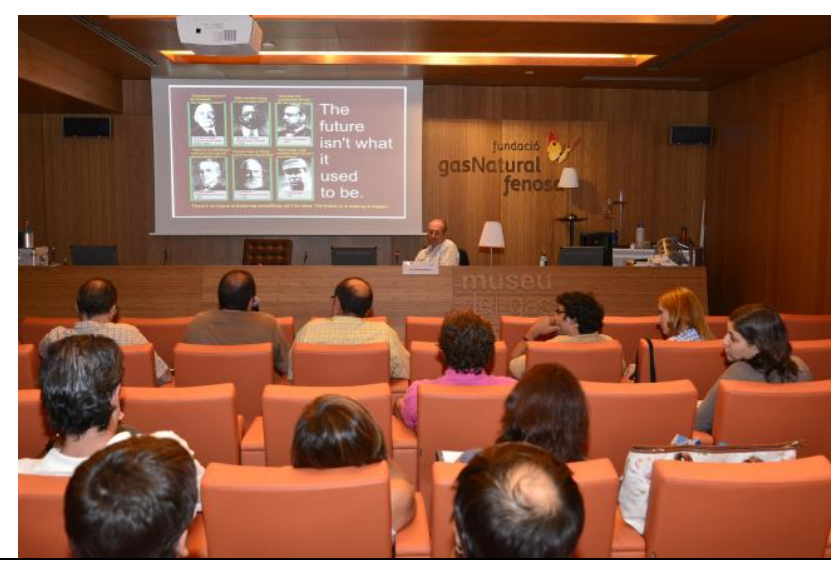

Figura 1. Conferència.

\section{Teoria i pràctica}

La primera jornada va comptar amb una conferència inaugural a càrrec de Dani Jiménez que va introduir el tema de l'energia d'una forma visual i espectacular per, a continuació, gaudir de la conferència del catedràtic i professor de la UAB Mariano Marzo sobre Recursos energètics. D'on ve l'energia?

Aquesta és una pregunta a la que, des del Museu del Gas de la Fundació Gas Natural Fenosa, es dona molt de valor en la didàctica de les energies, ja que es tracta d'un món massa complex com per poder resumir-lo amb l'evidència de que "de l'endoll de la paret en traiem electricitat" D'on ve? Com l'hem generada? És l'única manera d'aconseguir-la? Quina és la més eficient?

Aquestes i altres preguntes van trobar resposta durant la visita guiada a l'àmbit Les eines del futur, del Museu del Gas, a càrrec del Servei Educatiu del mateix museu.

Finalment el físic Dani Jiménez va oferir a tots els participants una sessió pràctica amb més d'una vintena d'experiments relacionats amb les energies i les propietats d'aquestes donant les eines als mestres i professors per poder desenvolupar-les posteriorment a l'aula.

La segona jornada començava el dissabte amb el dubte de Com utilitzar l'energia? Eficiència i bones pràctiques, a càrrec del comunicador ambiental i periodista, Jordi Bigues. A partir de tots els conceptes introduïts, el grup es va desplaçar al Mirador del Museu del Gas, de nou acompanyats de les responsables del Servei Educatiu, per descobrir quines són les mesures de sostenibilitat emprades a l'edifici que acull el Museu per tal 
d'estalviar un $51 \%$ d'energia respecte un edifici de referència.

Les darreres sessions de les jornades van incloure dos tallers sobre eficiència i sostenibilitat a càrrec de la pedagoga especialitzada en TIC i educació, Mireia Jiménez, que ens va descobrir tot un món de recursos a través de l'ordinador i la xarxa, i un segon taller en què, de la mà del geòleg expert en educació medi ambiental, Llorenç Planagumà, vam aprendre com construir un petit aerogenerador.

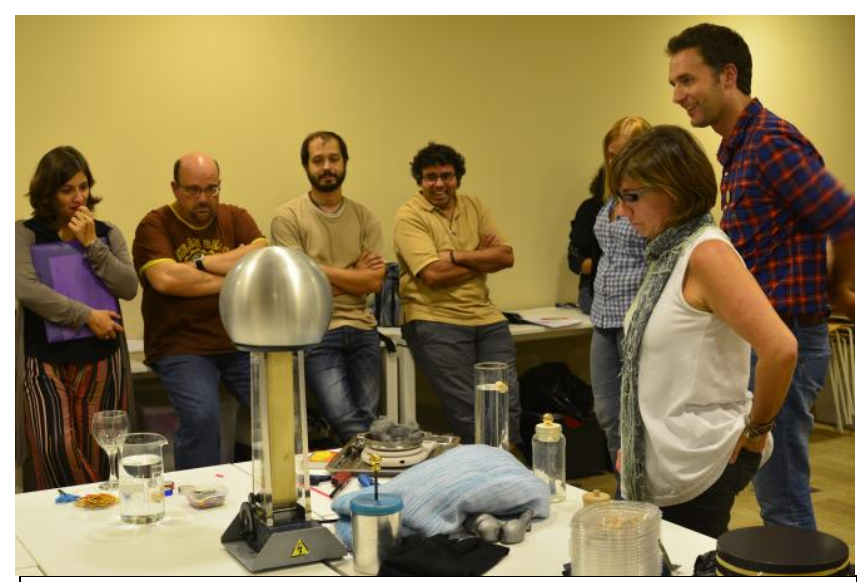

Figura 2. Conferència.

\section{Futures edicions}

La valoració que des del Museu del Gas de la Fundació Gas Natural Fenosa es fa de les jornades és molt positiva, destacant molt especialment la combinació de teoria i pràctica, la qualitat de les sessions, el contingut i els conferenciants, el material posat a l'abast dels participants i les instal-lacions on van tenir lloc les diferents sessions.

L'organització treballa ja en la preparació d'una segona edició amb l'objectiu de facilitar la tasca de mestres i professors, donar-los les eines i recursos necessaris per a poder desenvolupar la seva feina amb les màximes prestacions, i posicionar l'equipament del Museu del Gas de la Fundació Gas Natural Fenosa en un referent en la formació d'energia, tecnologia i sostenibilitat. 